\title{
RANCANG BANGUN SISTEM INFORMASI PELAYANAN PENUNJANG MEDIS LABORATORIUM DI PUSKESMAS KOPO BANDUNG
}

\author{
Rini Suwartika Kusumadiarti ${ }^{1}$ Rendra Ripandi $^{2}$ \\ Politeknik Piksi Ganesha \\ Program Studi Teknik Informatika Komputer ${ }^{1}$ \\ Program Studi Manajemen Informatika Konsentrasi Informatika Rekam Medis ${ }^{2}$ \\ rinisuwartika@yahoo.com ${ }^{1}$ \\ Ripandi74@gmail.com²
}

\begin{abstract}
Progress in the field of health is very rapidly in developing, so many findings are obtained with information technology assistance both in the field of organizing hospitals, health centers, treatment and development research from the health sciences itself. The combination of information technology with the activities of people who use these technologies, to support operations and management is an information system. This study aims to design and build an information system implementation of laboratory medical services in the UPT Kopo Bandung Health Center. Technique of data collection by means of observation, interviews and literature. Software development methods use the waterfall method with Data Flow Diagrams (DFD) as software design. The suggestions given to overcome the problems in the laboratory medical support system are: There needs to be a better development of the system. and need for training for HR who manage this system regarding the use of the application.
\end{abstract}

Keyword : Information System, Laboratory Service, Waterfall, Microsoft Visual Studio 2010

\begin{abstract}
Abstrak - Kemajuan dalam bidang kesehatan sangat berkembang dengan begitu pesat, sehingga banyak temuan-temuan yang didapatkan dengan bantuan teknologi informasi baik dalam bidang pengorganisasian rumah sakit, puskesmas, pengobatan maupun penelitian pengembangan dari ilmu kesehatan itu sendiri. Kombinasi antara teknologi informasi dengan aktivitas orang yang menggunakan teknologi tersebut, untuk mendukung operasi dan manajemen adalah sistem informasi. Penelitian ini bertujuan untuk merancang dan membangun implementasi sistem informasi pelayanan enunjang medis laboratorium di UPT Puskesmas Kopo BandungTeknik pengumpulan data dengan cara observasi, wawancara dan studi pustaka. Metode pengembangan perangkat lunak menggunakan metode waterfall dengan Data Flow Diagram (DFD) sebagai perancangan software. Adapun saran yang diberikan untuk mengatasi permasalahan dalam sistem pelayanan penunjang medis laboratorium adalah : Perlu adanya pengembangan sistem ke arah yang lebih baik, Perlu adanya pelatihan untuk SDM yang mengelola sistem ini terkait penggunaan aplikasi.
\end{abstract}

Kata Kunci : Sistem Informasi, Pelayanan Laboratorium, Waterfall, Microsoft Visual Studio 2010

\section{PENDAHULUAN}

Seiring berjalannya waktu dalam bidang teknologi dan komunikasi mengalami kemajuan sangat pesat sehingga berdampak pada dunia kesehatan yang mengalami kemajuan dalam pelayanan kesehatan yang diberikan kepada masyarakat. Salah satu kemajuan teknologi tersebut adalah teknologi informasi yang telah merambah keberbagai bidang kehidupan manusia. Defenisi teknologi informasi itu sendiri adalah study atau penggunaan peralatan elektronik, untuk menyimpan, menganalisa, dan mendistribusikan informasi. Salah satu kemajuan teknologi informasi merambah pada bidang kesehatan seperti kedokteran. Kemajuan dalam bidang kesehatan ini sangat berkembang dengan begitu pesat, sehingga banyak temuantemuan yang didapatkan dengan bantuan teknologi informasi baik dalam bidang pengorganisasian rumah sakit, puskesmas, pengobatan maupun penelitian pengembangan dari ilmu kesehatan itu sendiri. Kombinasi 
antara teknologi informasi dengan aktivitas orang yang menggunakan teknologi tersebut, untuk mendukung operasi dan manajemen adalah sistem informasi. Dalam arti yang sangat luas, istilah sistem informasi yang sering digunakan merujuk kepada interaksi antara orang, proses algoritmik, data dan teknologi. Faktor kesehatan merupakan salah satu faktor yang penting dalam kehidupan masyarakat. Untuk mendapatkan layanan kesehatan ketika sakit diperlukan suatu badan atau organisasi yang berperan dalam memberikan pelayanan kesehatan yang memadai contohnya seperti puskesmas. sebagai fasilitas kesehatan tingkat pertama dituntut untuk memberikan pelayanan kesehatan yang efektif dan efesien agar dapat meningkatkan pelayanan kesehatan dan meningkatkan derajat kesehatan secara optimal di lingkungan masyarakat maka perlu adanya organisasi yang menangani proses pencatatan data dan informasi pasien yang berkunjung yang dinamakan Rekam Medis. Semua informasi mengenai pasien yang berkunjung dicatat dan disimpan dalam dokumen rekam medis. Menurut permenkes

NO.269/MENKES/PER/III/2008 menyebutkan bahwa setiap sarana pelayanan kesehatan wajib menyelenggarakan rekam medis. Rekam medis adalah berkas yang berisikan catatan dan dokumen tentang identitas pasien, hasil pemeriksaan, pengobatan, tindakan dan pelayanan yang telah diberikan kepada pasien. Didalam keterangan tersebut sudah tercermin segala informasi yang menyangkut seseorang pasien yang akan dijadikan dalam menentukan informasi yang menyangkut seseorang pasien yang akan dijadikan dasar dalam menentukan tindakan lebih lanjut dalam pelayanan maupun tindakan medis lain yang diberikan kepada seseorang pasien yang datang ke rumah sakit (Rustiyanto,2010). Puskesmas menurut (Effendi,2009) adalah Unit Pelaksana Teknis Dinas kesehatan yang bertanggung jawab dalam menyelenggarakan pembangungan kesehatan di wilayah kerjanya. Sebagai penyelenggara pembangunan kesehatan, puskesmas bertanggung jawab menyelenggarakan upaya kesehatan perorangan dan upaya kesehatan masyarakat, yang ditinjau dari Sistem Kesehatan Nasional merupakan pelayanan tingkat pertama selain pelayanan medis puskesmas juga mempunyai jenis pelayanan penunjang medis. Penunjang medis adalah pelayanan yang bersifat menunjang pelayan medis yang berfungsi agar pengobatan dan perawatan yang diberikan lebih maksimal. Laboratorium kesehatan di puskesmas merupakan salah satu bagian pelayanan utama yang menunjang kegiatan pelayanan kesehatan di setiap puskesmas. Peranan laboratorium di puskesmas saat ini telah menjadi bagian yang cukup di perlukan, karena dibutuhkan untuk menentukan suatu diagnosa penyakit. Pengelolaan laboratorium kesehatan didasarkan pada peraturan menteri kesehatan Republik Indonesia nomor 37 tahun 2012. Menurut peraturan menteri kesehatan yang dimaksud dengan laboratorium puskesmas adalah sarana pelayanan kesehatan puskesmas yang melaksanakan pengukuran, penetapan, dan pengujian terhadap bahan yang berasal dari manusia untuk menentukan jenis penyakit, penyebab penyakit, kondisi kesehatan, atau faktor yang dapat berpengaruh pada kesehatan perorangan dan masyarakat. Sistem yang berjalan di UPT Puskesmas Kopo Kota Bandung mengenai pelayanan penunjang medis laboratorium masih dilakukan secara manual, petugas laboratorium masih mencatat data pasien dan hasil laboratorium dibuku register, pembuatan hasil pemeriksaan laboratorium sangat lama dan pembuatan laporann laboratorium masih dilakukan secara manual.

\section{LANDASAN TEORI}

\section{A. Pengertian Puskesmas}

Menurut Keputusan Menteri Kesehatan RI Nomor 128/MENKES/SK/II/2004, Puskesmas adalah Unit Pelaksana Teknis (UPT) dari Dinas Kesehatan Kabupaten/Kota yang bertanggung jawab menyelengggarakan pembangunan kesehatan disuatu wilayah kerja.

\section{B. Sistem Pelaporan dan Pencatatan Puskesmas}

Menurut SK MENKES/SK/II/1981 ditetapkan Sistem Pencatatan dan Pelaporan Terpadu Puskesmas adalah kegiatan pencatatan dan pelaporan data umum, sarana, tenaga dan upaya pelayanan kesehatan di puskesmas yang bertujuan Meningkatkan kualitas manajemen Puskesmas secara lebih berhasil guna dan berdaya guna melalui pemanfaatan secara optimal data SP2TP dan informasi lain yg menunjang, ada beberapa jenis laporan yang dibuat oleh puskesmas, antara lain:

1.Laporan harian untuk melaporkan kejadian luar biasa penyakit tertentu.

2.Laporan mingguan untuk melaporkan kegiatan penyakit yang sedang ditanggulangi 
3. Laporan bulanan untuk melaporkan kegiatan rutin progam. Laporan jenis ini ada 4 jenis yaitu:

a. LB1, berisi data kesakitan

b. LB2, berisi data kematian

c. LB3, berisi data progam gizi, KIA, KB, dll

d. LB4, berisi data obat-obatan

\section{Pengertian Rekam Medis}

Menurut permenkes

No. 269/MENKES/PER/III/2008 rekam medis adalah berkas yang berisikan catatan dan dokumen tentang identitas pasien, pemeriksaan, pengobatan, tindakan dan pelayanan lain yang telah diberikan kepada pasien.

\section{Pengertian Laboratorium}

Laboratorium medis adalah laboratorium dimana berbagai macam tes dilakukan pada spesimen biologis untuk mendapatkan untuk mendapatkan informasi tentang kesehatan pasien. Laboratorium ini terdiri dari berbagai jenis pemeriksaan menurut Sriasi Gandahusada (2007:122) dalam buku parasitology klinik diantaranya adalah sebagai berikut :

a. Mikrobiologi menerima usapan, tinja, air seni, darah, dahak, peralatan medis, begitupun jaringan yang mungkin terinfeksi. Spesimen tadi dikultur untuk menerima pathogen.

b. Parasitologi mengamati parasit.

c. Hematologi menerima keseluruhan darah dan plasma. Mereka melakukan penghitungan darah dan selaput darah.

d. Koagulasi menganalisis waktu bekuan dan faktor koagulasi.

e. Kimia klinik biasanya menerima serum. Mereka menguji serum untuk komponen-komponen yang berbeda.

f. Toksikologi menguji obat farmasi, obat yang disalahgunakan dan toksin lain.

g. Imunologi menguji antibodi.

h. Imunohematologi atau bank darah menyediakan komponen, derivat dan produk untuk transfuse.

i. Serologi menerima sempel serum untuk mencari bukti penyakit seperti hepatitis atau HIV.

j. Urinalisis menguji air seni untuk sejumlah analit.

k. Histologi memproses jaringan padat yang diambil dari tubuh untuk membuat di kaca mikroskop da menguji detail sel.

1. Sitologi menguji usapan sel (seperti dari mulut rahim) untuk membuktikan kanker dan keadaan lain. m. Sitogenetika melibatkan penggunaan darah dan sel lain untuk mendapatkan kariotipe, yang dapat berguna dalam diagnosis prenatal (mis sindrom down) juga kanker (beberapa kanker memiliki kromosom abnormal).

n. Virologi dan analisi DNA juga dilakukan di laboratorium klinik yang besar.

o. Patologi bedah menguji organ, ekstremitas, tumor, janin dan jaringan lain yang dibiopsi pada bedah seperti masektomi payudara.

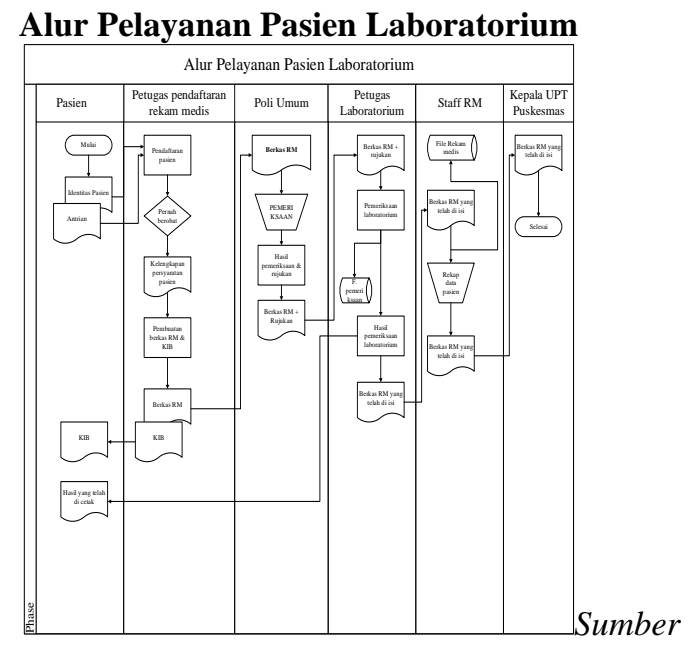

:Puskesmas (2018)

\section{E. Pengertian Perancangan}

Menurut Ladjamudin (2005 : 51) Perancangan adalah suatu kegiatan yang memiliki tujuan untuk mendesign sistem baru yang dapat menyelesaikan masalah-masalah yang dihadapi perusahaan yang diperoleh dari pemilihan alternatif sistem yang baik, sedangkan Menurut Darmawan (2013 : 227) Perancangan Adalah Spesifikasi umum dan terinci dari pemecahan masalah berbasis computer yang telah dipilih selama tahap analisis.

\section{F. Pengertian Data Flow Diagram}

Menurut Alpin Laduni (2012:10) Data Flow Diagram (DFD) adalah suatu diagram yang menggunakan notasi-notasi untuk menggambarkan arus dari data sistem, yang penggunaannya sangat membantu untuk memahami sistem secara logika, terstruktur dan jelas.

\section{III.METODE PENELITIAN}

Menurut Notoatmojo (2008:138) "metode penelitian deskriptif adalah suatu metode 
penelitian yang dilakukan dengan tujuan utama untuk membuat gambaran atau deskripsi tentang suatu keadaan secara objektif. Metode penelitian deskripsi digunakan untuk memecah atau menjawab permasalahan yang sedang dihadapi pada masa sekarang.

\section{A. TEKNIK PENGUMPULAN DATA}

Teknik pengumpulan data dalam menyelesaikan skripsi ini adalah :

a. Wawancara

Wawancara adalah salah satu teknik pengumpulan data dengan cara mengajukan pertanyaan langsung yang dilakukan pewawancara kepada responden, yang hasil dari jawaban responden tersebut dicatat atau diekam.

b. Studi Pustaka

Studi pustaka adalah teknik pengumpulan data yang tidak langsung ditujukan pada subyek penelitian, namun melalui dokumen atau referensi buku ilmiah yang digunakan penulis untuk mendukung penelitian yang sedang dilaksanakan.

\section{B. METODE}

PENGEMBANGAN

\section{PERANGKAT LUNAK}

Linear sequential (atau disebut juga "classic life cycle" atau "waterfall method") adalah metode pengembangan perangkat lunak dengan pendekatan ekuensial

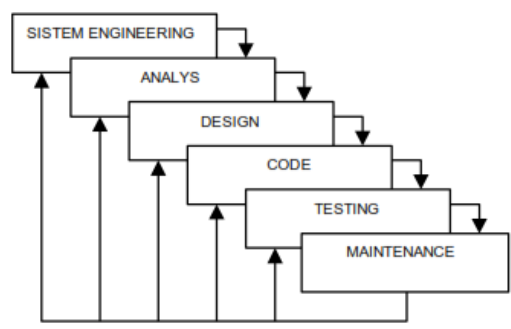

Gambar 1. Metode Waterfall

\section{IV.HASIL DAN PEMBAHASAN}

Untuk alat bantu perancangan system, penulis menggunakan DFD (Data Flow Diagram)

\section{A. PERANCANGAN \\ INFORMASI}

1. Flowmap Sistem Yang Dirancang

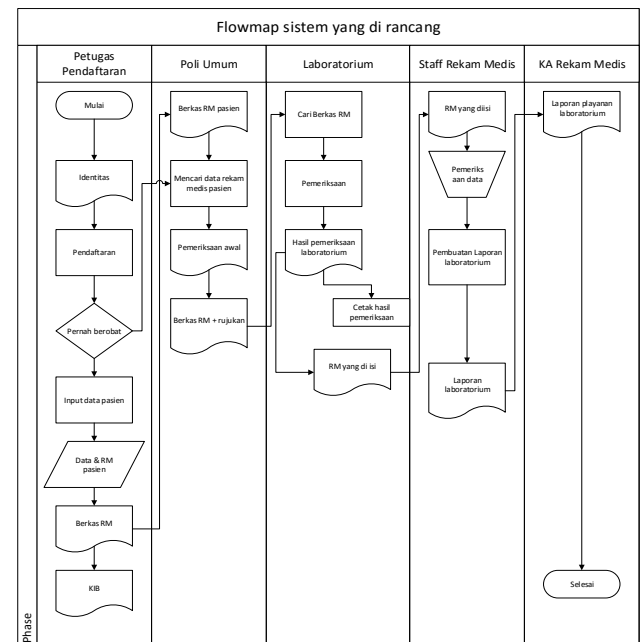

Gambar 2. Flowmap Sistem

\section{DFD Sistem Yang Dirancang}

a. Konteks Diagram Sistem

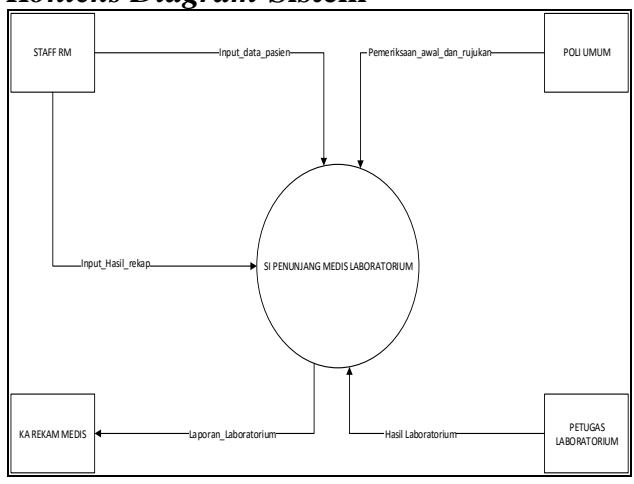

Gambar 3. Diagram Konteks Sistem

b. Data Flow Diagram (DFD) Level 0

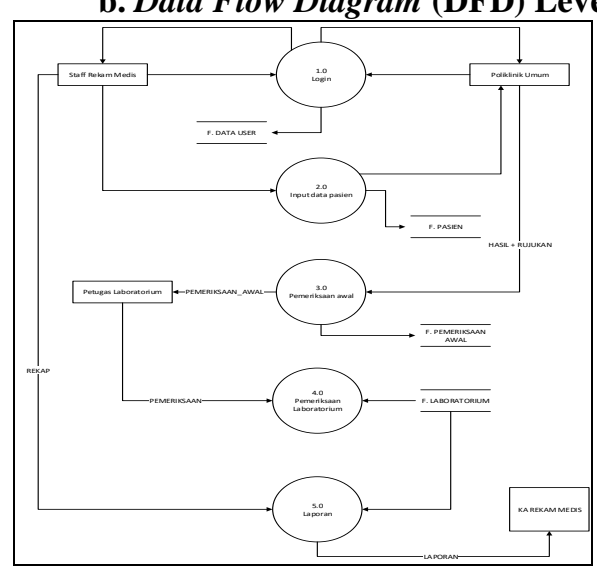

Gambar 4. Data Flow Diagram (DFD) Level 0 
c. Data Flow Diagram (DFD) Level 1 Proses 1

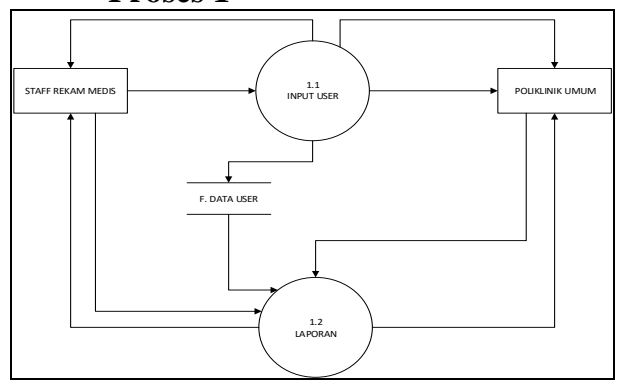

Gambar 5. Rancangan Data Flow Diagram (DFD) Level 1

d. Data Flow Diagram (DFD) Level 1 Proses 2

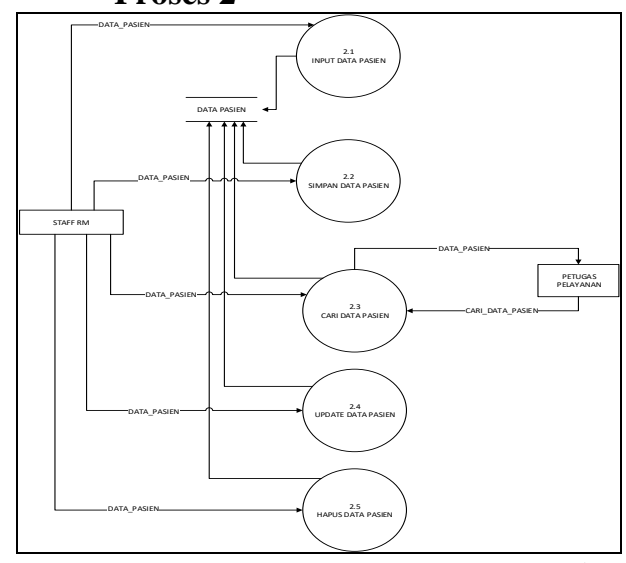

Gambar 6. Rancangan Data Flow

Diagram (DFD) Level 1 Proses 2

e. Data Flow Diagram (DFD) Level 1 Proses 3

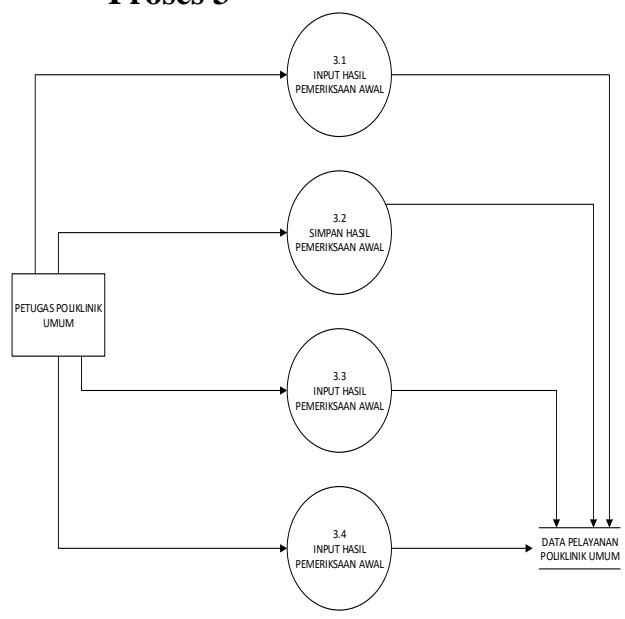

Gambar 7. Rancangan Data Flow Diagram (DFD) Level 1 Proses 3

f. Data Flow Diagram (DFD) Level 1 proses 4

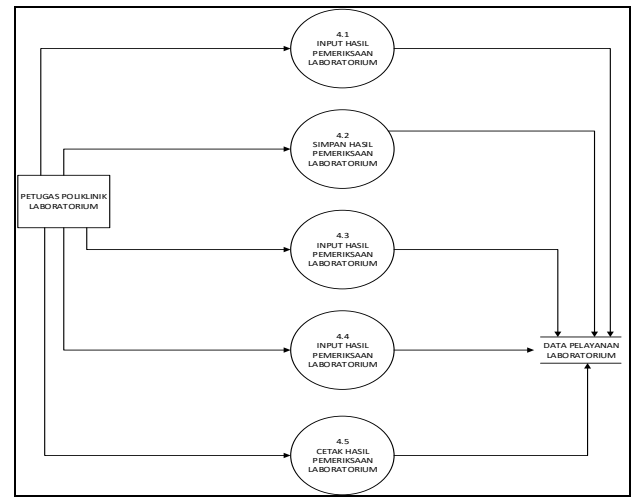

Gambar 8. Rancangan Data Flow Diagram (DFD) Level 1 Proses 4 Data Flow Diagram (DFD) Level 1 proses 5

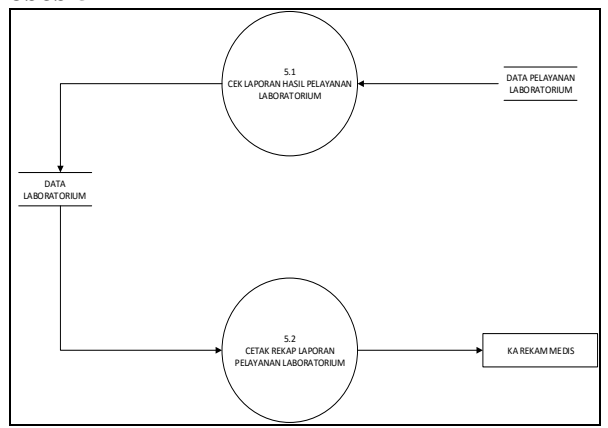

Gambar 9. Rancangan Data Flow Diagram (DFD) Level 1 Proses 5

g. Entity Relationsip Diagram (ERD)

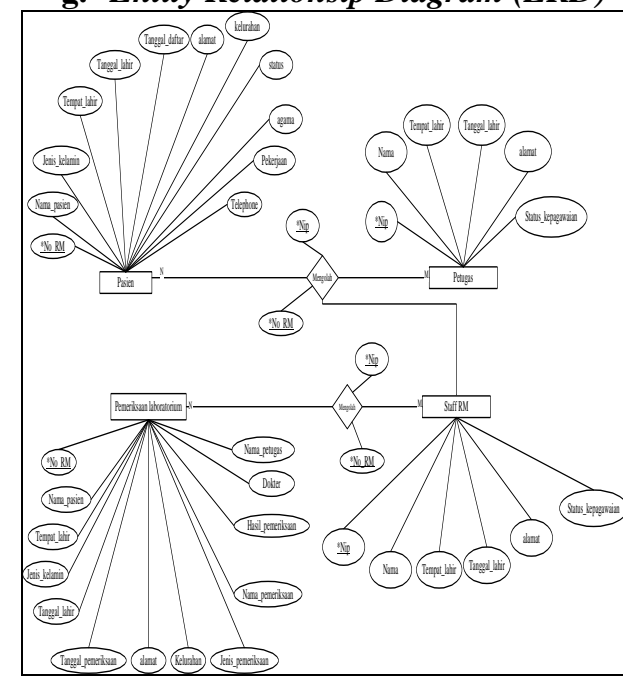

Gambar 10. Rancangan Entity Relationsip Diagram 


\section{h. Relasi Basis Data}

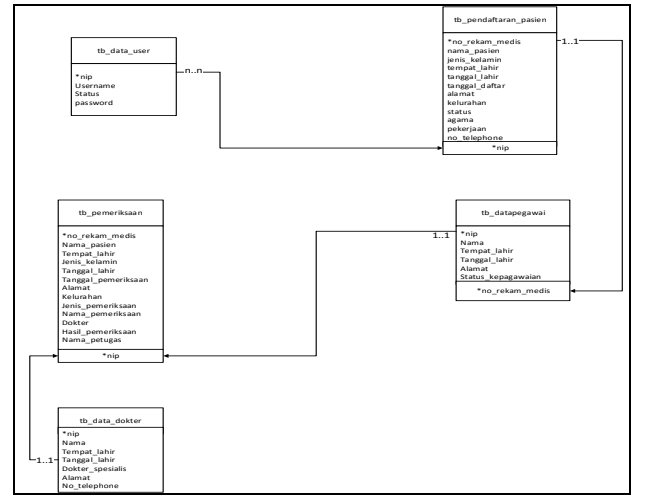

Gambar 11. Rancangan Relasi Basis Data

\section{B. IMPLEMENTASI}

Tahap implementasi sistem merupakan tahap menerjemahkan perancangan berdasarkan hasil analisis dalam bahasa yang dapat dimengerti oleh mesin serta penerapan perangkat lunak pada keadaan yang sesungguhnya.

\section{Tampilan Form Login}

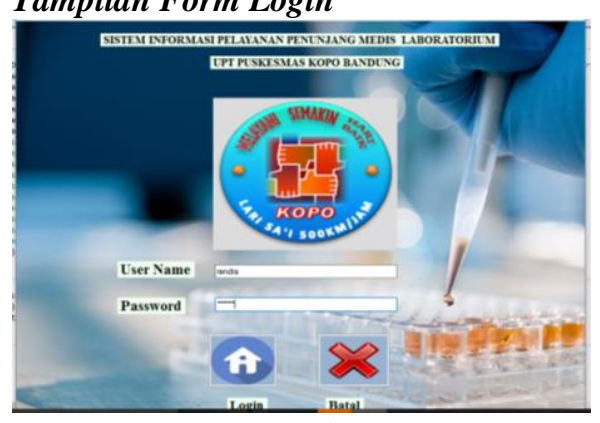

Gambar 12. Tampilan Form Login

2. Tampilan Form Menu Utama

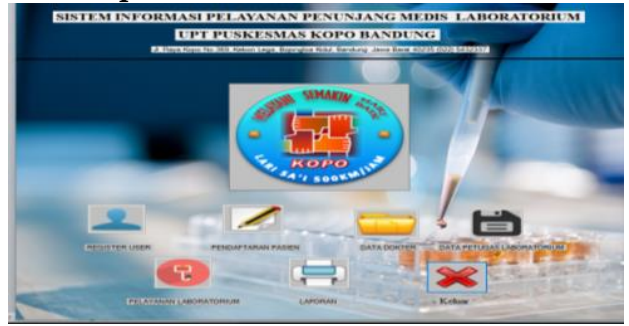

Gambar 13. Tampilan Form Menu Utama

3. Tampilan Form Register User

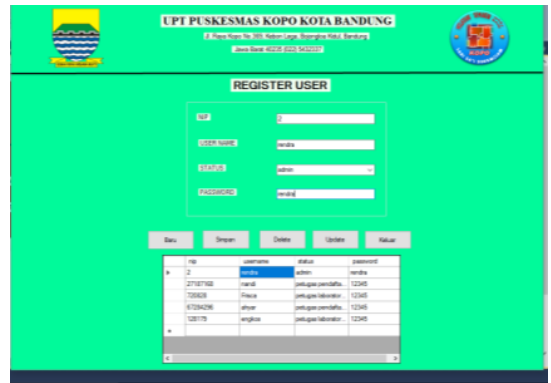

Gambar 14. Tampilan Form Register User

4. Tampilan Form Identitas Data Dokter

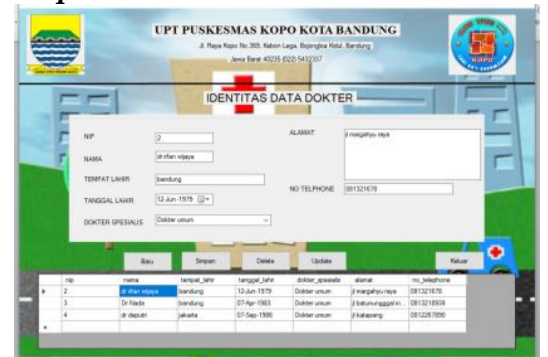

Gambar 15. Tampilan Form Identitas Data Dokter

5. Tampilan Form Input Data Petugas

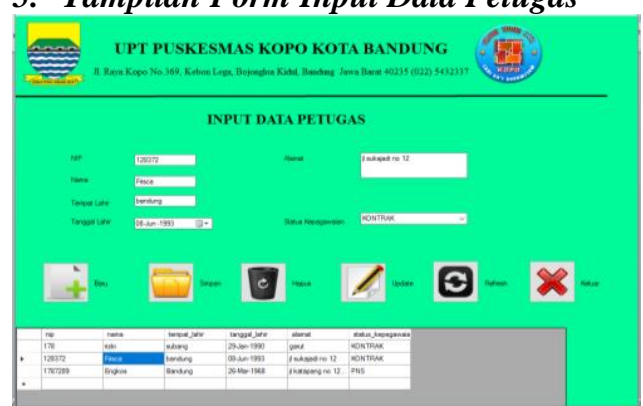

Gambar 16. Tampilan Form Pendaftaran Pasien

6. Tampilan Form Pendaftaran Pasien

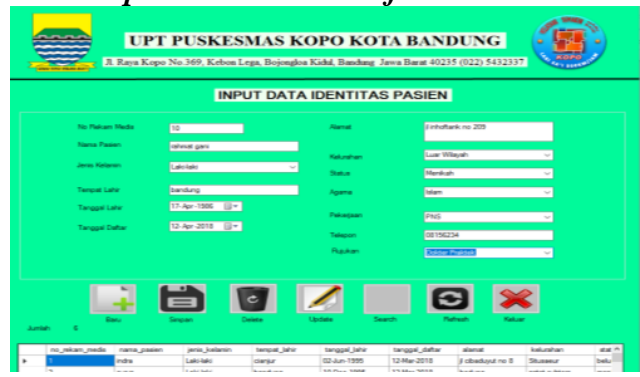

Gambar 17. Tampilan Form Pelayanan

7. Tampilan Form Pemeriksaan
Laboratorium




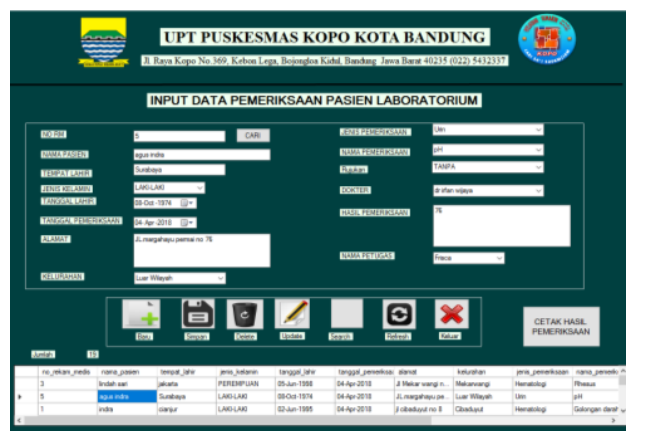

Gambar 18. Tampilan Form Pemeriksaan Laboratorium

\section{Tampilan Form Laporan Laboratorium}

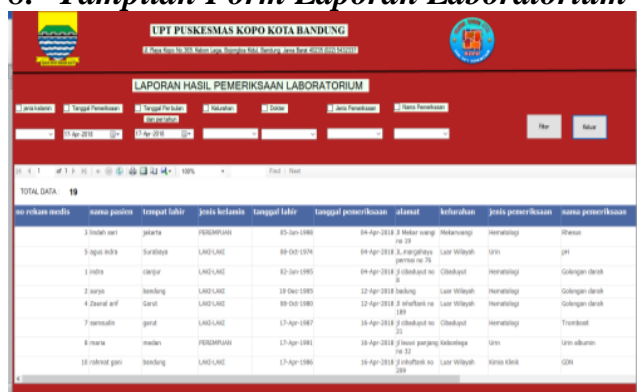

Gambar 19. Tampilan Form Laporan Laboratorium

\section{KESIMPULAN DAN SARAN}

\section{A. Kesimpulan}

Berdasarkan Penelitian yang dilakukan, Laboratorium kesehatan di puskesmas merupakan salah satu bagian pelayanan utama yang menunjang kegiatan pelayanan kesehatan di setiap puskesmas. Peranan laboratorium di puskesmas saat ini telah menjadi bagian yang cukup di perlukan, karena dibutuhkan untuk menentukan suatu diagnosa penyakit, Oleh karena itu penggunaan teknologi yang tepat dirasa akan sangat membantu dalam prosedur pelayanan pasien dan memudahkan pihak puskesmas dalam melayani kebutuhan para pasiennya.

\section{B. Saran}

Berdasarkan kesimpulan di atas, maka penulis memberikan saran kepada UPT puskesmas Kopo Bandung yaitu sebagai berikut

a. Perlu adanya pengembangan sistem ke arah yang lebih baik

b. Perlu adanya pelatihan untuk SDM yang mengelola sistem ini terkait penggunaan aplikasi.

c. Melakukan pemeliharaan sistem untuk menjaga sistem dalam keadaan baik d. Adanya pengembangan program dengan fitur-fitur yang lebih baik lagi.

\section{DAFTAR PUSTAKA}

[1] Keputusan Menteri Kesehatan RI No.932 Tahun 2000 Tentang Pelaksanaan Manajemen Kesehatan Yang Terdapat Di Puskesmas.

[2] Peraturan Menteri Kesehatan RI No. 75 Tahun 2004 Pasal 2 Tentang Tujuan Puskesmas

[3] Peraturan Menteri Kesehatan RI No. 269/Menkes/PER/III/2008 Tentang Rekam Medis \& Rekam Medis Elektronik.

[4] Undang-Undang N.29 Tahun 2004 Tentang Praktik Kedokteran.

[5] A.M Hirin, (2011), VB.NET 2010, Bangau, Yogyakarta.

[6] Fatta, Hanif Al (2007), Analisis dan Perancangan Sistem Informasi, ANDI: Yogyakarta.

[7] Huffman, (1994), Medical Record Management, Phisycian Record Company

[8] Hartono Jogiyanto, (2004), Pedoman Informasi Komputer, Graha Ilmu, Yogyakarta.

[9] Kristanto Andri, (2008), Perancangan Sistem Informasi dan Aplikasinya, Gava Media, Yogyakarta.

[10] Ladjamudin Al-Bahra Bin, (2005), Perancangan Sistem Informasi Graha Ilmu, Yogyakarta

[11] Potter \& Perry, (2009), Fundamental Of Nursing $7^{\text {th }}$ Edition, Missouri, St.Louis

[12] Sutanta Edhy, (2003), Sistem Basis Data \& Sistem Informasi Manajemen, Graha Ilmu, Yogyakarta 